IRA-International Journal of Applied Sciences

ISSN 2455-4499; Vol.04, Issue 03 (2016)

Institute of Research Advances

Pg. no. 379-393

http://research-advances.org/index.php/IRAJAS

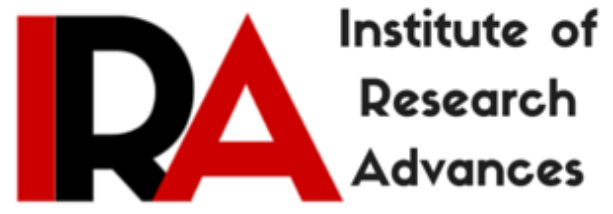

\title{
Reckoning of water quality with using GPS system for Irrigation purpose in Coastal areas of Sirkali Taluk of Nagapattinam District, Tamilnadu-India
}

\author{
N. Pasupathy ${ }^{1}$, A. Arokiyaraj ${ }^{2}$ \\ ${ }^{1}$ Research scholar, Department of Chemistry, A.V.C.College (Autonomous), \\ Mannampandal-609 305, Mayiladuthurai, Tamilnadu, India. \\ ${ }^{2}$ PG,Research Department of Chemistry, A.V.C.College (Autonomous), \\ Mannampandal-609 305, Mayiladuthurai, Tamilnadu, India.
}

Type of Review: Peer Reviewed.

DOI: http://dx.doi.org/10.21013/jas.v4.n3.p2

\section{How to cite this paper:}

Pasupathy, N., \& Arokiyaraj, A. (2016). Reckoning of water quality with using GPS system for Irrigation purpose in Coastal areas of Sirkali Taluk of Nagapattinam District, Tamilnadu-India. IRA-International Journal of Applied Sciences (ISSN 2455-4499), 4(3), 379-393. doi:http://dx.doi.org/10.21013/jas.v4.n3.p2

(C) Institute of Research Advances

\section{(cc) EY-NC}

This work is licensed under a Creative Commons Attribution-Non Commercial 4.0 International License subject to proper citation to the publication source of the work.

Disclaimer: The scholarly papers as reviewed and published by the Institute of Research Advances (IRA) are the views and opinions of their respective authors and are not the views or opinions of the IRA. The IRA disclaims of any harm or loss caused due to the published content to any party. 


\begin{abstract}
Agriculture is the backbone of developing countries, the 26, December 2004 'Tsunami' had a major impact on the quality of groundwater along the south-east coast of India, but especially in the tsunami-affected coastal areas of SirkazhiTaluk of the Nagapattinam district of Tamilnadu, India. Major pollution resulted primarily from increases in the salinity of ground water. The post- tsunami water quality posed problems to general health and contributed significantly to agricultural and environmental degradation in the same districts. The present study focus on analysis of underground water quality parameter for irrigation purpose in coastal area. Totally, 105 water samples were collected from different locations. GPS technique is used to identify the coastal area and collected the samples. Physiochemical parameters such as $\mathrm{pH}$, electrical conductivity(EC), total dissolved solids(TDS), carbonate, bicarbonate, chloride, calcium, magnesium, sulfate, sodium, potassium of all collected samples were analyzed to determine the contamination. The sodium adsorption ratio (SAR) and residual sodium carbonate (RSC) levels were also calculated using standard equations. The results showed the significant variations in water quality in the study area, which helped analysis suitable to irrigation purpose in future.
\end{abstract}

Key words: irrigation water, physicochemical parameter, RSC, SAR, Salinity

\title{
INTRODUCTION
}

Irrigation water quality belongs to the suitability for its use for irrigation purposes. Good quality water is the thinkable to maximize crop yield under good soil and water management practices. After all, with poor quality water, soil and cropping problems can be conventional to reduce yield unless special management practices are adopted to counteract these problems. Capability problems, resulting from using poor quality water, vary conforming to the kind and the degree of hazards caused by the use of such water (Bassuony, 2014). poor quality of groundwater/drainage water increases soil salinity, and with decreased crop yields besides effecting structural deterioration of agricultural lands. The poor quality of the irrigation water applied will also affect the soil chemical properties which further predominance soil dispersion, aggregate breakdown, surface sealing and crust formation (Shainberg and Letey 1984).Sodic soils are associated with structural changes that principally affect permeability of soils. Effect of salinity and alkalinity of water is extensively studied under saturated (Chaudhari and Somawanshi 2004, Dane and Klute 1977) and unsaturated conditions (Quirk and Schofield 1955, Mclntyre 1979, Shainberg et al., 2001, Levy et. al., 2005,). Soil accumulated stability, slaking and dispersion were related to SAR and electrolyte concentration by Abu-Sharar et al. (1987). Increasing sodicity and decreasing the concentration of the applied water pyramidsphysico-chemical dispersion. This diffusion, in turn, leads to a reduction in soil hydraulic conductivity (Shainberg and Letey, 1984,Pupisky and Shainberg, 1979, Frenkel et al., 1978). If the level of Na+ in the soil is high, the colloidal portion behavior will be affected. High carbonate ( $\left.\mathrm{CO}^{-}\right)$and bicarbonate (HCO3-) in water essentially increases the sodium hazard of the water to a level greater than that demonstrate by the SAR. High CO3= and $\mathrm{HCO} 3$ - tend to precipitate calcium carbonate $(\mathrm{CaCO} 3)$ and magnesium carbonate $(\mathrm{MgCO} 3)$ when the soil solution concentrates during soil drying. The consolidation of calcium and magnesium in the soil solution are reduced relative to sodium and the SAR of the soil solution tends to increase. When high consolidation of sodium affect a soil, the trailing loss of structure reduces the hydraulic conductivity. (Hardy et al., 1983 ,Shainberg and Letey, 1984, Hanson et al.,1999, and Levy et al.,1999). Limited freshwater opportunity and increasing demand on food are making even marginal and poor quality waters, an important source for irrigation. The salt effect on soil hydraulic properties would not be ignored because it can lead to serious degradation of irrigated soils (Dane and Klute 1977). The above information all told, the contaminated irrigation water is affected soil (structure, nutrient elements), plants and crop yields.Sirkazhi Taluk was a major cultivated area in Nagapattinam district at before the tsunami, especially near costal revenue villages was a highly paddy growing area in sirkazhi Taluk.But the tsunami 
incident totally changed that, lot of irrigation water contaminated by salinity water. So yield reduction was step by step decreased. Above ten thousand hectares of agricultural lands are not cultivated now. A formers are losing their lives. Fig.1.shows the Satellite imge of cultivation affected areas by saline water in sirkazhi taluk.

\section{MATERIALS AND METHODS}

\section{Study Area}

Nagapattinam district ,the land of religious harmony, known for its rich religious heritage was carved out by bifurcating the composite Thanjavur district on 18-10-1991. This district is spread over eight taluk with a total geographical extent of 2715.83 sq.km with the head Quarters at Nagapattinam .This district lies on the shores of the Bay of Bengal,between Northern Latitude 10.7906 degrees and 79.8428 degrees Eastern Longitude .The district capital 'Nagapattinam' Lies on the eastern coast ,350 kilometers down south from the state capital 'Chennai' and 145 kilometers east, from Tiruchirappalli a central place of the state. The study area is sirkazhi Taluk of Nagapattinam district coastal region in the southern Tamilnadu State located in the coastal region of the Bay of Bengal 11.0290373 Latitude and 79.8506815 Longitude. This taluk is spread over in 27,726 hectares of Agriculture land. Table.1 shows the study area and GPS location.

\section{Water Sampling}

Totally 105 irrigation water sample was collected 35 costal revenue villages by using white colour polystyrene bottle of one liter capacities .Before collecting the samples, the bottle was washed properly and rinsed thoroughly several times with same underground water. Each sample were labeled with correct GPS location and address for analysis purpose. The underground water sample were collected of location data shown in Table.1.Then the quality of underground water analyzed in the laboratory determined many parameters such as $\mathrm{pH}, \mathrm{EC}, \mathrm{TDS}, \mathrm{Ca}, \mathrm{Mg}, \mathrm{Na}, \mathrm{K}, \mathrm{SO}_{4}, \mathrm{Cl}, \mathrm{CO}_{3}$, and $\mathrm{HCO}_{3}$ are determined by standard methods and by using standard instruments. Then the water quality results are compared with standard values Recommended by World Health Organization (WHO) and Bureau of Indian Standards (BIS) for irrigation purpose.

\section{Global Positioning System (GPS) System}

The GPS surveying techniques ware used to identify the specific locations of various underground water samples situated at different villages of the costal area table.1.Since the global positioning system (GPS) is an integral part of topographic surveys. The GPS datasets were originally stored as point measurement. Each point had northing, easting, and elevation values.

\section{Water quality measurements}

The water $\mathrm{pH}, \mathrm{EC}, \mathrm{TDS}$, Cations and Anions were determined as follows:

i. The water reaction $(\mathrm{pH})$ was determined using a $\mathrm{pH}$ meter (802, digital $\mathrm{pH}$ meter,Systronics).

ii. The total soluble salts were measured by using an Electrical conductivity meter (EC) in $\mathrm{dS} / \mathrm{m}^{-1}$ at $25^{0} \mathrm{C}$ (MK-509, Systronics )

iii. The soluble Cations was determined by using Flame photometer apparatus ( $\mu$ Controller Based Flame photometer with CompressorType : 128,systronics)

iv. The soluble anions was determined by using Titrimetric method. 


\section{Some quality important water ratings For irrigation purpose recommended by WHO,BIS}

\section{Electrical conductivity(EC)}

Meaning its electrical conductivity expressed in $\left(\mathrm{dsm}^{-1}\right)$ represents the total. Salt content of irrigation water. The major anions are carbonates, bicarbonates, sulphate and chloride with low concentric of fluride and nitrate. Table.3, shows classification of irrigation water based on Electrical Conductivity.

\section{Sodium Absorption Ratio (SAR)}

$$
\mathrm{SAR}=\mathrm{Na}^{2+} / \sqrt{ } \mathrm{Ca}^{2+} \mathrm{Mg}^{2+} / 2
$$

The ratio of sodium contents to that of calcium and magnesium in the water is called Sodium Absorption Ratio. Sodium Absorption Ratio also denotes sodium hazard. Table.4, shows classification of irrigation water based on Sodium Absorption Ratio.

\section{Residual Sodium Carbonate (RSC)}

Residual Sodium Carbonate indicates bicarbonate hazard. It is determined by the proportion of carbonate ions to that of calcium and magnesium ions

$$
\operatorname{RSC}(\mathrm{Meq} / \mathrm{lit})=\left(\mathrm{CO}_{3}{ }^{2+}+\mathrm{H} \mathrm{CO}_{3}{ }^{2+)}-\left(\mathrm{Ca}^{2+}+\mathrm{Mg}^{2+}\right)\right.
$$

The increased Residual Sodium Carbonate value leads to alkali formation because of the precipitation of calcium and magnesium carbonate/ bicarbonate or sodium and bicarbonate. Table.5, shows classification of irrigation water based on Residual Sodium Carbonate.

\section{Geo Chemical Type}

Geo chemical type refers to predominate soluble salt present in the irrigation water . The broad Geo chemical type are,

\section{Chloride Water, 2.Sulphate Water, 3.Bicarbonate}

Calcium bicarbonate and calcium sulphate waters have the low conductance, Sodium chloride water has the highest conductance, when calcium and magnesium is more than half of the total cations it is considered calcium/ magnesium type. When sodium and potassium is more than half of the total cations, the water is considered sodium type. If bicarbonate is than $50 \%$ of the total anions, it is considered type. The content of chloride plus sulphate exceeds $50 \%$ of the total anions, it is considered chloride type. Table.4, shows problems associated with some Geo Chemical types of water.

\section{Result and Discussion}

The revenue village wise water sample analysis reports are presented in the (table.7). $\mathrm{pH}$ is one of the important parameters of irrigation water .Generally $\mathrm{pH}$ values for normal irrigation water should be between 6-7.Above value are considered as of increasing hazard (Singh e tat.2000, Danko,1997).The $\mathrm{pH}$ is logarithmic, meaning that a change of 1.0 units is a tenfold change in either basicity or acidity. Therefore a change of even less than 1.0 units may be significant. The result showing that the $\mathrm{pH}$ value in all locations and in the all the samples ranging from 7.25 to 8.18 in sirkazhi Taluk at costal revenue village (Table.7 and Fig.5). The minimum $\mathrm{pH}$ value 7.25 is at Mangaimadam and the maximum $\mathrm{pH}$ value 8.18 is Maadhanam . The very more level,pH value is present in three villages such as (Arapallam 8.05,Melaiyur 8.10,and Maadhanam 8.18). 
The concentration of the total salt content in irrigation water is estimated in terms of Electrical conductivity (EC) and it may be the most important parameter for assessing the suitability of irrigation water (Belan,1985, Ayayi e tal.,1990) Generally, the ranges considered for irrigation water suitability are from 0 to $2.0\left(\mathrm{dsm}^{-1}\right)$ (WHO,BIS). Above value is considered salinity hazards.The EC in all locations range from 0.9223 to 2.39. The minimum EC value 0.9223 is at Edamanal and the maximum EC value at 2.39 is Pazhaiyapalaiyam, and the average EC value is in all locations 1.56(Table.7). Based on the electrical conductivity classification, $8.57 \%$ of villages cover under C1classification and this village underground water does not have salinity, $70.43 \%$ of villages cover under C2 classification and this village underground water contains Medium salinity level ,and 20\% of villages cover under the $\mathrm{C} 3$ classification its denoted this village's water have salinity(Fig.2).

Total dissolved solid (TDS) is also a criterion for the assessment of salt content in the water as salts constitute an important part of TDS (FAO,1985). The irrigation water with total dissolved solid (TDS) is considered suitable and good , and more than $2000 \mathrm{mg} / \mathrm{l}$ is unsuitable to irrigation purpose.The TDS in all location ranges from 591 to $1529.66 \mathrm{mg} / \mathrm{l}$.The minimum TDS value $591 \mathrm{mg} / \mathrm{l}$ is at Varisaipathvadagal, maximum TDS value $1529.66 \mathrm{mg} / \mathrm{l}$ at Pazhaiyapalaiyam and the average value is in all locations $1003.46 \mathrm{mg} / \mathrm{l}$ (Table.7 and Fig.6).

Sodium Absorption Ratio also denotes sodium hazard .Based on Sodium Absorption Ratio classification.100\% of villages cover under the S1 classification, it denotes all location underground waters have a safe sodium hazard. And $0 \%$ of villages cover under S2,S3 classification (Fig.3). Residual Sodium Carbonate indicates bicarbonate hazard. It is determined by the proportion of carbonate ions to that of calcium and magnesium ions. Based on Residual Sodium Carbonate classification, $88.57 \%$ of villages cover under R1 classification, $8.57 \%$ of villages cover under R2 classification and $2.86 \%$ of villages cover under R3 classification ( Fig.4).

Geo chemical type refers to predominate soluble salt present in the irrigation water.)Based on Geo chemical type, $28.57 \%$ of villages cover under $\mathrm{NaCl}$ type, $40 \%$ for $\mathrm{NaHCO}_{3}, 11.44 \%$ for $\mathrm{MgHCO}_{3}, 8.57 \%$ for $\mathrm{CaHCO}_{3}$ and $\mathrm{CaCl}_{2}, 2.85 \%$ villages cover under $\mathrm{MgCl}_{2}$ type(Fig.7).

\section{Conclusion}

The result of the waters samples investigation shows that the six Geo chemical types waters were identified, such as $\mathrm{CaHCO}_{3}, \mathrm{NaHCO}_{3}, \mathrm{MgHCO}_{3}, \mathrm{CaCl}, \mathrm{NaCl}, \mathrm{MgCl}$. Accordingly , permanent hardness and salinity problems are probable. Based on Electrical Conductivity $8.57 \%$ of the waters have excellent irrigation water quality, $70.43 \%$ of the waters have medium salinity and $20 \%$ of the waters have high salinity or doubtful to irrigation, there is a risk of yield production for most of commonly cultivated crops. Based on sodium hazard $100 \%$ of the waters have good quality, they are in safe against to sodium hazard. Based on carbonate hazard $88.57 \%$ of the waters have excellent quality, $8.57 \%$ of the waters have moderate carbonate hazard and $2.86 \%$ of the waters have highly carbonate hazard or unsafe irrigation waters. Finally ,based on Geo chemical types $8.57 \%$ of the waters are in calcium bicarbonate type, it indicates this waters have low concentration and it does not give any problem to cultivation. $40 \%$ of the waters are in sodium bicarbonate type, it indicates this water has intermediate concentration and alkalinity problem. $11.43 \%$ of the waters are in magnesium bicarbonate type it is similar to calcium bicarbonate and it indicates this water have low concentration and it does not give give problem. $29 \%$ of the waters are in sodium chloride type, it indicates this waters have high concentration or alkalinity problem $.8 .57 \%$ of the waters are in calcium chloride type, its indicate this water have high concentration and high salinity problem. And $2.85 \%$ of the waters are in magnesium chloride type, it indicates this waters have moderate salinity problem. 


\section{REFERENCES}

Abu-Sharar T.M., Bingham, F.T., Rhoades, J.D., 1987. Soil Science Society of America Journal.51- 342.

Ajayi, F.M.,Nduru ,A.,Oningue., 1990. "Halting the salt that kills crops African farmer” No.4,pp10-12

Bassuony.,Ali.,Abdel Hameed.,Jahin.,2014. "Evaluvation of irrigation water quality in different regions of north east delta-egypt".

Belan ,F.I.,1985. Water treatment .Mir Pulishers Moscow.,USSR,232P3

Chaudhari,S.K.,Somawanshi,R.B.,2004. "Predicting sodium dynamics by mechanistic and layer mod- els in different textural soils". Communication in soil science and plant analysis 35, Nos.19\&20, pp. 2941-2956.

Dane,J.H., Klute, A.,1977. "Salts effects on the hy- draulic properties of a swelling soil". Soil Science Society American Journal 41,1043-1049.

Danko, M.M., 1997. "Comparative analysis of variables of irrigation water quality along river Rima”.B.Aricultural project, department of soil science and Agricultural Engineering, Usman Danfodio University, Sokoto .pp.45

Drinking Water Standards of BIS (IS: 10500: 1991)

FAO.,1985. Guidelines .Land evaluation for Irrigated Agriculture. Soil Bull.No.55, FAO Room Italy.

Frenkel, H., Goertzen, J.O., Rhoades, J.D., 1977. "Effects of clay type and content, exchangeable sodium percentage, electrolyte concentration on clay dispersion and soil hydraulic conductivity". Soil Science Society of America Journal 42, 32- 39.

Hanson, B., Grattan, S.R., Fulton, A., 1999, Agricultural Salinity and Drainage. University of California Irrigation Program. University of California, Davis.

Hardy, N., Shainberg, I., Gal, M., Keren, R., 1983. "The effect of water quality and storm sequence upon infiltration rate and crust formation". Journal of Soil Science, 34, 665-676.

Levy, G.J., Rosenthal, A., Torchitzky, J., Shainberg, I., Cehn, Y., 1999. "Soil hydraulic conductivity changes caused by irrigation with reclaimed waste waters". Journal of Environmental Quality 28, 1658-1664.

Levy, G.J., Goldstein, D., Mamedov, A.I., 2005. "Saturated hydraulic conductivity of semiarid soils combined effects of salinity, sodicity, and rate of wetting". Soil Science Society of America Journal 69,653-662.

McIntyre, D.S., 1979. "Exchangeable sodium, subplasticity and hydraulic conductivity of some Australian soils". Journal of Soil Research 17, 115-120.

Pupisky, H., Shainberg, I.,1979. "Salt effect on the hydraulic conductivity of a sandy soil. Soil”. Science Society of America Journal 43,429-433. 
Quirk, J.P.,Schofield, R.K., 1955. "The effect of electrolyte concentration on soil permeability”. Journal of Soil Science 6, 163-1780

Shainberg, I.,Letey, J., 1984. Response of soils to sodic and saline conditions, Hilgardia 52(2), 1- 57.

Shainberg, I., Levy, G.J., Goldstein, D., Mamedov, A.I., Letey, J.,2001. "Prewetting rate and sodicity effects on the hydraulic conductivity of soils". Australian Journal of Soil Research 39, 1279- 1291.

Singah, B.R.,2000 . "Quality of irrigation water in Fadama Lands North-western Nigeria".I. Ground and surface water in kebbi State .Nig.J.Basic.And.Apl.Sci.9,133-148.

WHO.,2004. [Online] Available.,www.who.int/water_sanitationhealth/publications/facts2004/en/index.html.

World Health Organization ,WHO., 2004. Guidelines for Drinking Water Quality., Vol. 1 Recommendations $3{ }^{\text {rd }}$ edn., WHO, Geneva. 
(Tables \& Figures)
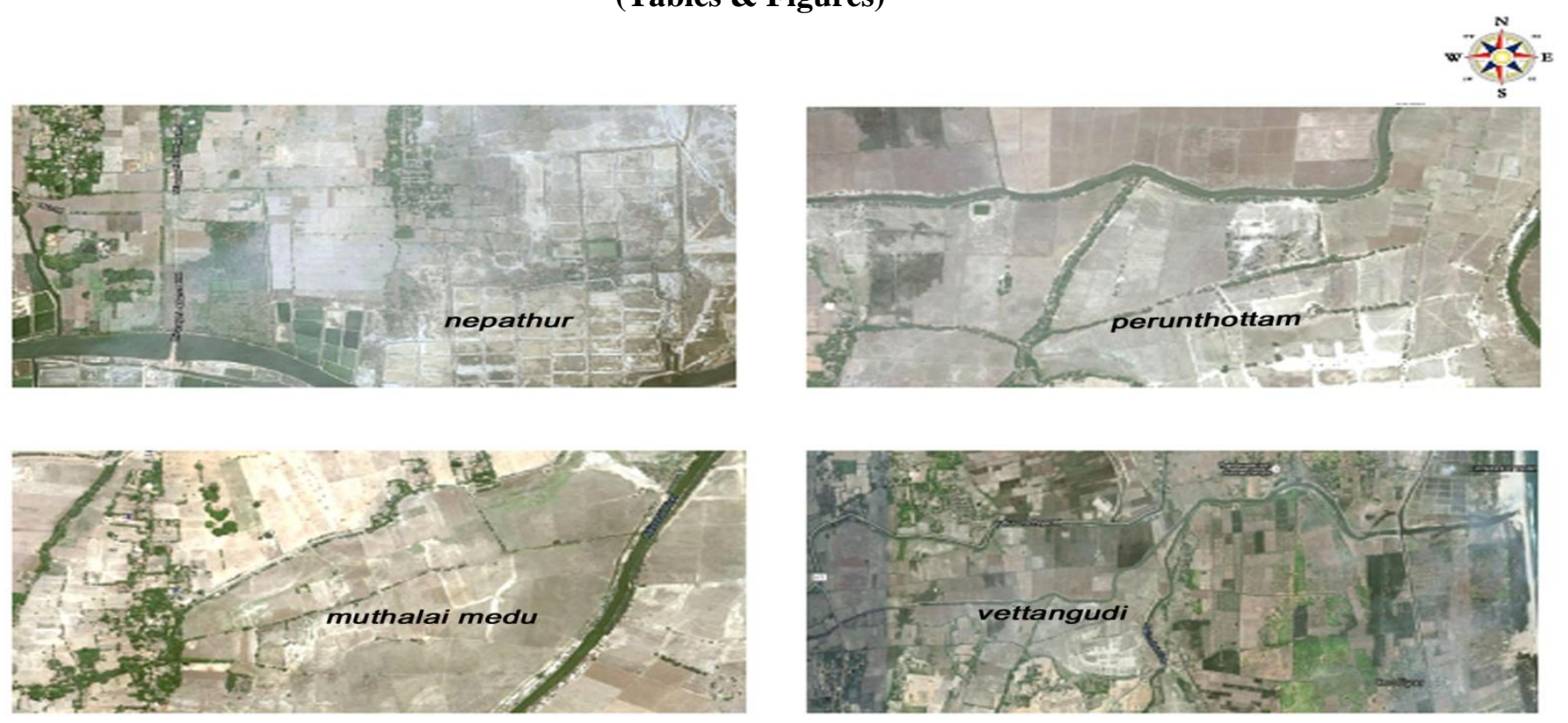

Fig.1.Satellite imge of cultivation affected areas by saline water in sirkazhi taluk

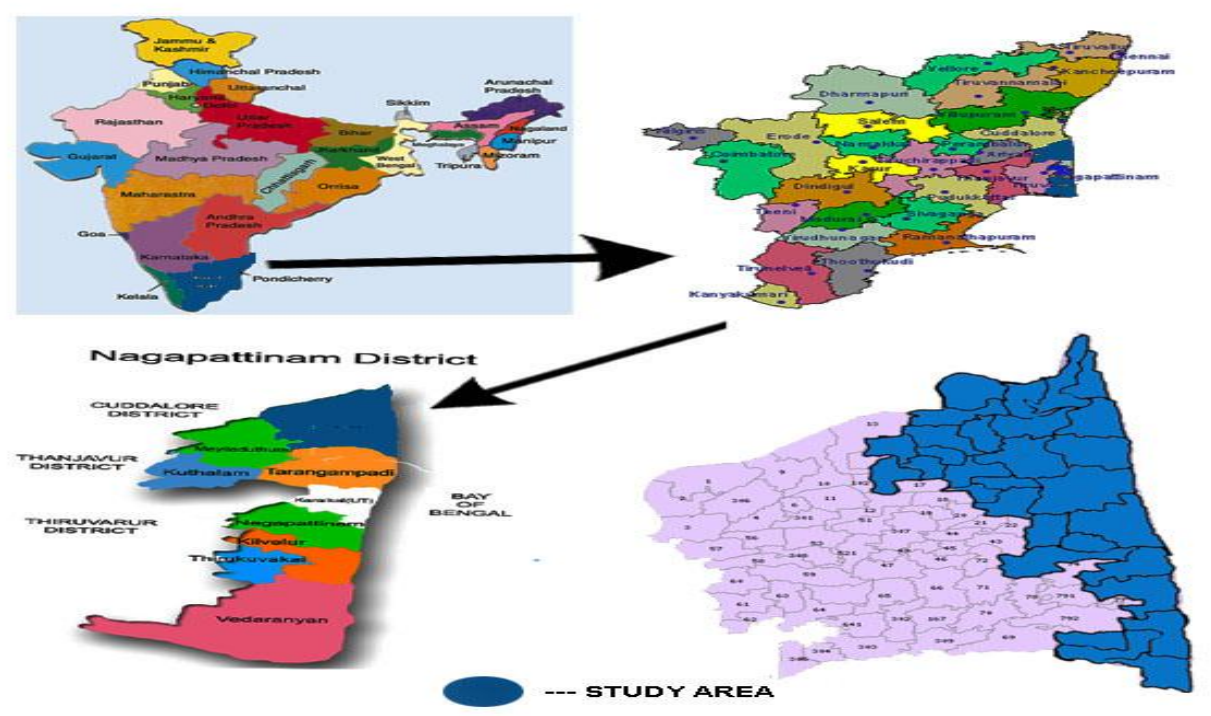

Fig.2. location map of sample collected costal area of Sirkazhi Taluk-Tamilnadu 


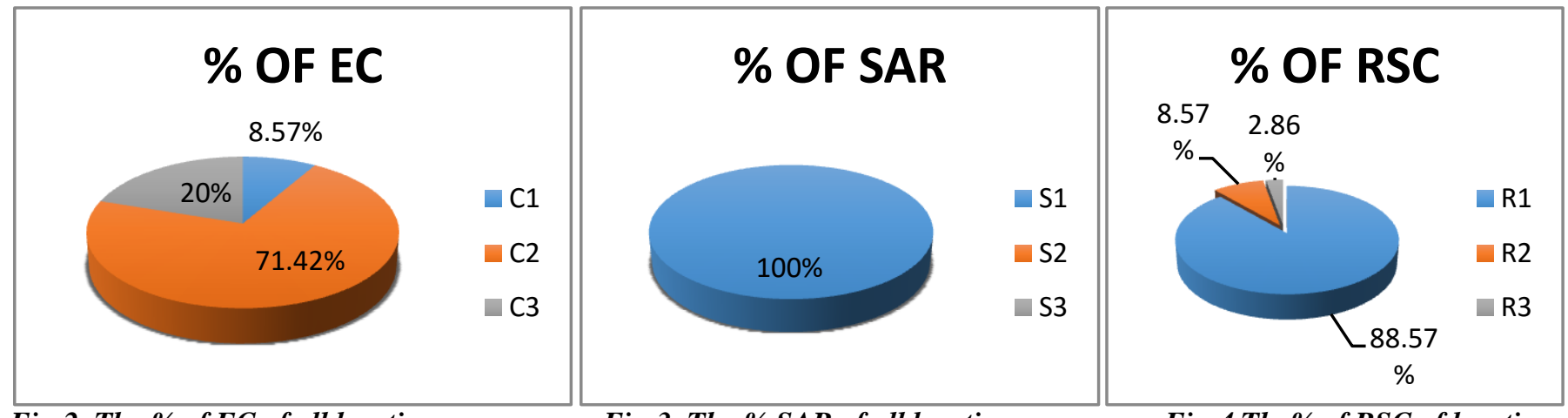

Fig:2. The \% of EC of all location

Fig:3. The \% SAR of all location

Fig:4.The\% of RSC of location

\section{pH Value of All Costal Revenue Villages}

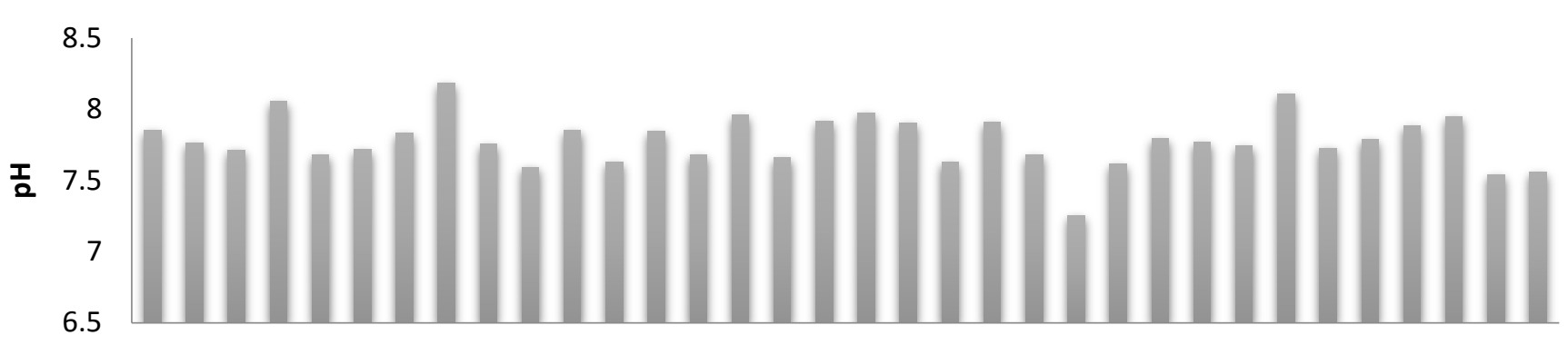

$1 \quad 2 \quad 3 \quad 4 \quad 5 \quad 6 \quad 7 \quad 8 \quad 9 \quad 10111213141516171819202122232425262728293031323334$

Fig:5.The pH value of all costal revenue village of SirkazhiTaluk,Nagapattinam District-Tamilnadu

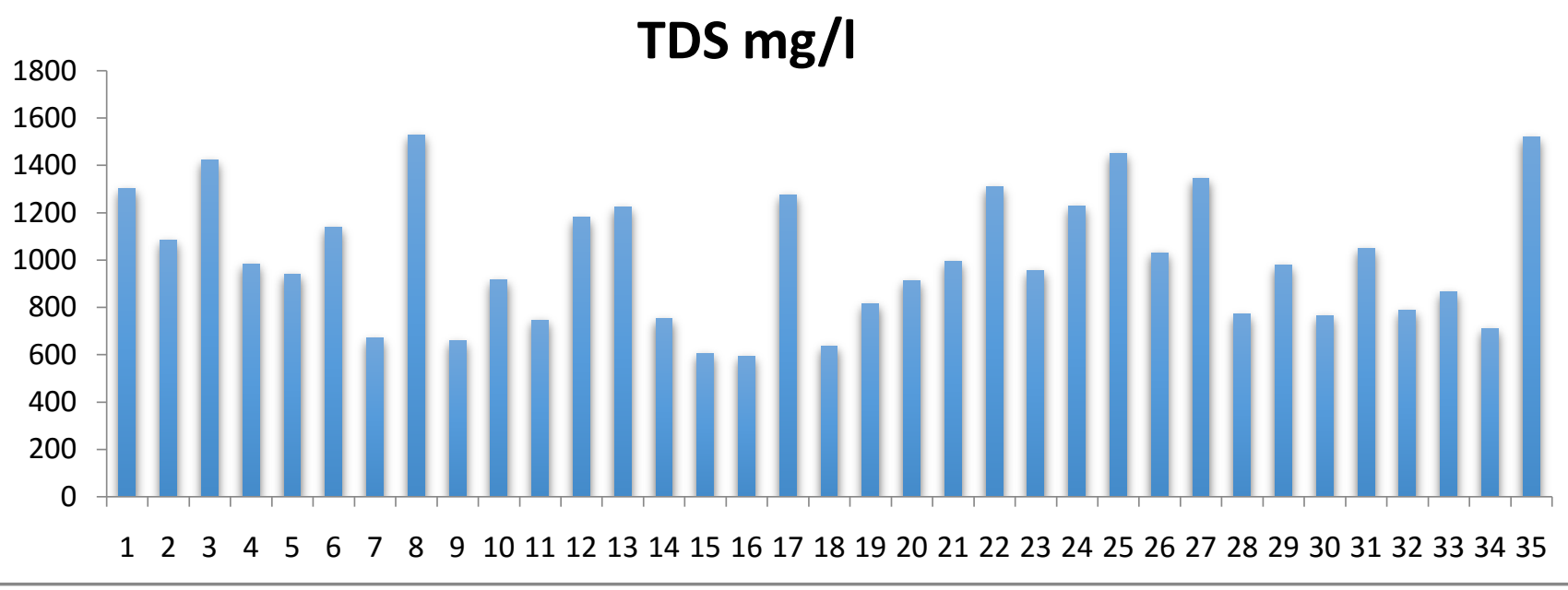

Fig:6.The TDS value of all costal revenue village of SirkazhiTaluk,Nagapattinam District-Tamilnadu 


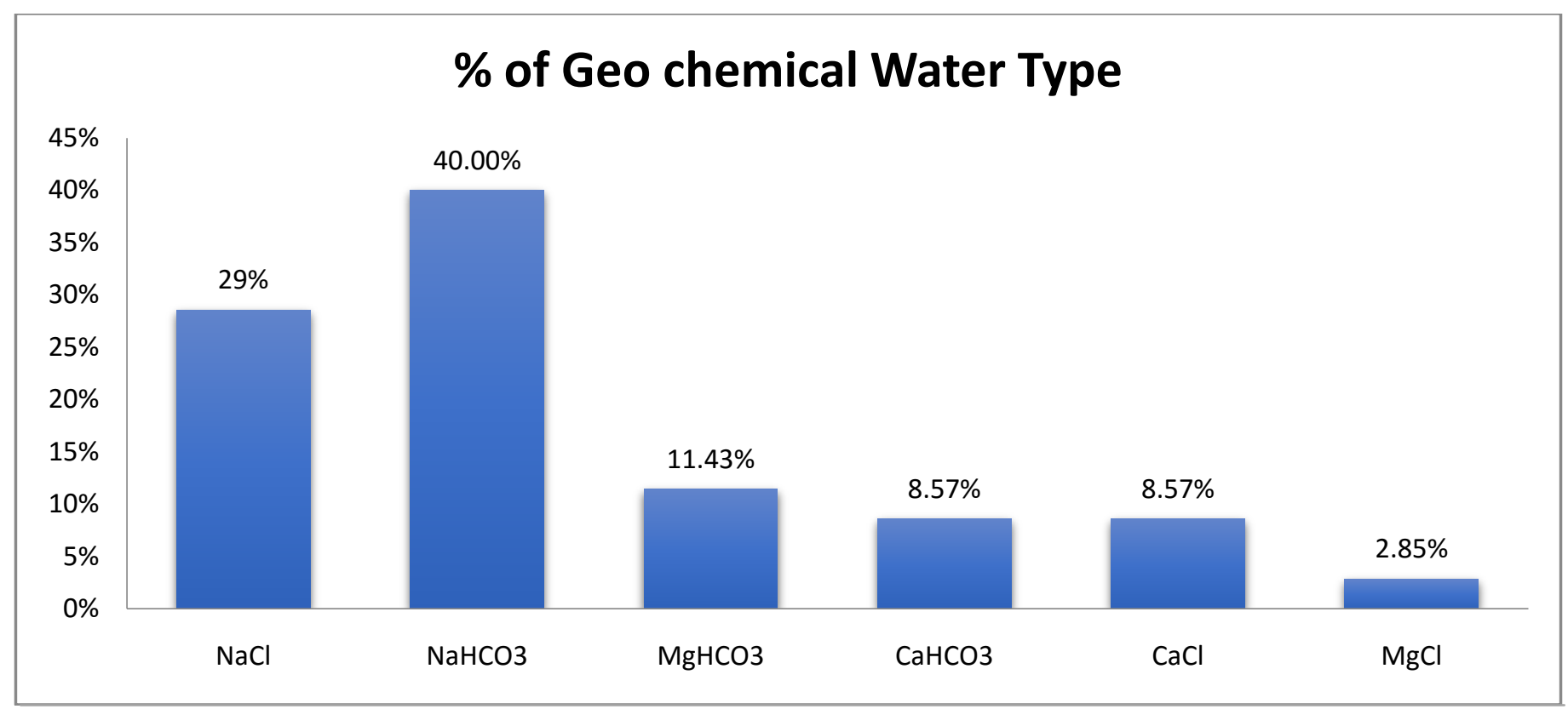

Fig:7.The \% of Various Type Water In Costal Revenue Village Sirkazhitaluk-Nagapattinam District 
Table:1.Gps Location Data of Sample Collected Coastal Area of Sirkazhi Taluk -Tamilnadu

\begin{tabular}{|c|c|c|c|c|c|c|c|}
\hline \multirow[t]{2}{*}{ S.NO } & \multirow[t]{2}{*}{ VILLAGE NAME } & \multicolumn{2}{|c|}{ SAMPLE-1 LOCATION } & \multicolumn{2}{|c|}{ SAMPLE-2 LOCATION } & \multicolumn{2}{|c|}{ SAMPLE-3 LOCATION } \\
\hline & & LONGITUTE $^{0} \mathrm{E}$ & LATITUTE $^{0} \mathrm{~N}$ & LONGITUTE $^{0}$ E & LATITUTE $^{0} \mathrm{~N}$ & LONGITUTE $^{0} \mathrm{E}$ & LATITUTE $^{0} \mathrm{~N}$ \\
\hline 1 & ALAKUDI & 79.7 .69122 & 11.374512 & 79.7098206 & 11.3468035 & 79.7130885 & 11.383628 \\
\hline 2 & MEHENTRAPALLI & $79^{0} .767089$ & 11.3552895 & 79.792311 & 11.365823 & 79.790460 & 11.363629 \\
\hline 3 & PUTH & 79.8131648 & 11.3193474 & 79.810300 & 11.331299 & 79.811824 & 11.331363 \\
\hline 4 & MUDHALAIMEDU & 79.7513063 & 11.3305297 & 79.7591976 & 11.3429095 & 79.769434 & 11.350886 \\
\hline 5 & AARAPALLAM & 79.7591976 & 11.3429095 & 79.7670123 & 11.3550131 & 79.7532172 & 11.3401644 \\
\hline 6 & PULIYANDHURAI & 79.8136559 & 11.348863 & 79.767089 & 11.3552895 & 79.7642389 & 11.3521932 \\
\hline 7 & THANDAVANGULAM & 79.8131648 & 11.3193474 & 79.799558 & 11.2806557 & 79.807361 & 11.303528 \\
\hline 8 & PAZHAIYAPALAIYAM & 79.7792386 & 11.288338 & 79.8065089 & 11.3157187 & 79.7877799 & 11.2934519 \\
\hline 9 & MAADHANAM & 79.7513063 & 11.3305297 & 79.758874007 & 11.29835216 & 79.766153 & 11.298055 \\
\hline 10 & KATT & 79.7131821 & 11.4113457 & 79.8136559 & 11.348863 & 79.7776476 & 11.3922826 \\
\hline 11 & AHARAVATTARAM & 79.774278 & 11.2896393 & 79.7767583 & 11.2889887 & 79.7792386 & 11.288338 \\
\hline 12 & MAHARAJAPURAM & 74.7792386 & 11.288335 & 79.8157375 & \begin{tabular}{|l|}
11.24777415 \\
\end{tabular} & 79.7746362 & 11.2936038 \\
\hline 13 & VETTANGUD & 79.7860874 & 11.2702060 & 79.79207 & 11.2520318 & 79.7792678 & 11.2883813 \\
\hline 14 & ALANGADU & 79.755763 & 11.2483195 & 79.750619 & 11.2483021 & 79.7706846 & 11.2581747 \\
\hline 15 & KADA & 79.79207 & 11.2520318 & 79.79281 & 11.2520420 & 79.7838591 & 11.252372 \\
\hline 16 & VARISAIPATHU VADAKAL & 79.7792678 & 11.2883813 & 79.78815 & 11.253912 & 79.784243 & 11.255267 \\
\hline 17 & THIRUMULLAI VASAL & 79.8192325 & 11.2403698 & 79.8106432 & 11.2289728 & 79.7934645 & 11.2061788 \\
\hline 18 & EDAMANAL & 79.7706846 & 11.2581747 & 79.7690291 & 11.2510061 & 79.7706846 & 11.2581747 \\
\hline 19 & RADHANALLUR & 79.8192325 & 11.2403698 & 79.8060697 & 11.2462008 & 79.8204342 & 11.2410063 \\
\hline 20 & THIRUKARAIKKAYUR & 79.7772445 & 11.2374523 & 79.7672145 & 11.2481231 & 79.7823418 & 11.223541 \\
\hline 21 & THIRUNAHARI & 79.8192325 & 11.2403698 & 79.7964963 & 11.2097911 & 79.787469 & 11.2096313 \\
\hline 22 & THENNAMPATTINAM & 79.8033508 & 11.2255006 & 79.787459 & 11.2096313 & 79.8140009 & 11.2179338 \\
\hline 23 & & 79.7934645 & 11.2061785 & 79.7435231 & 11.2062341 & 79.7904667 & 11.2079051 \\
\hline 24 & MANGAIMAD & 79.80857159 & 11.18948806 & 79.81176731 & \begin{tabular}{|l|}
11.18950784 \\
\end{tabular} & 79.804993 & 11.194661 \\
\hline 25 & MUTHAL PERUNHOTTAM & 79.83082618 & 11.20162288 & 79.83132686 & 11.20140694 & 79.831363828 & 11.2013948 \\
\hline
\end{tabular}


IRA-International Journal of Applied Sciences

\begin{tabular}{|l|l|l|l|l|l|l|l|}
\hline 26 & IRANDAMPERUNTHOTTAM & 79.831584109 & 11.831584109 & 79.8317513210 & 11.20127706 & 79.8282915865 & 11.1956221 \\
\hline 27 & AHARA PERUNTHOTTAM & 79.822035 & 11.189204 & 79.822654 & 11.185583 & 79.824159 & 11.184741 \\
\hline 28 & MANIKIRAMAM & 79.824556 & 11.1452993 & 79.8199747 & 11.1488791 & 79.8199747 & 11.1488791 \\
\hline 29 & MELAIYUR & 79.8199747 & 11.1468791 & 79.8053401 & 11.1844758 & 79.8392016 & 11.1567777 \\
\hline 30 & KEEZHAIYUR & 79.8392016 & 11.156777 & 79.8392016 & 11.1567777 & 79.8392016 & 11.1567771 \\
\hline 31 & VANAKIRI & 79.8291373 & 11.1417196 & 79.8291373 & 11.1417196 & 79.83991615 & 11.1453899 \\
\hline 32 & ALALASUNTHARAM & 79.797515067 & 11.31897286 & 79.752399731 & 11.31864689 & 79.7431296314 & 11.3182432 \\
\hline 33 & ACHALAPURAM & 79.7254736 & 11.3099142 & 79.7564412 & 11.3289478 & 79.7532767758 & 11.3266757 \\
\hline 34 & NALLANAYAKKA PURAM & 79.74282631 & 11.31834750 & 79.742739482 & 11.31843785 & 79.742584143 & 11.3183520 \\
\hline 35 & UMAIYAL PETTAI & 79.7713634 & 11.2584211 & 79.7713634 & 11.2584211 & 79.764766 & 11.264640 \\
\hline
\end{tabular}

Table :2. These ratings could be used as guidelines when recommendation are given

\begin{tabular}{|c|c|c|c|}
\hline Water Quality Ratings & EC $\left(\mathrm{dsm}^{-1}\right)$ & $\begin{array}{c}\text { SAR } \\
\text { (Meq/lit) }\end{array}$ & $\begin{array}{c}\text { RSC } \\
\text { (Meq/lit) }\end{array}$ \\
\hline Good & Less than 2.0 & Less than 10.0 & Nil \\
\hline Marginal water & $2-4$ & Less than 10.0 & Less than 2.5 \\
\hline Saline water & More than 4.0 & Less than 10.0 & Nil \\
\hline Sodic water & Less than 4.0 & More than 10.0 & Usually more than 2.5 \\
\hline
\end{tabular}

Table :3.Calassification of irrigation water based on electrical conductivity

\begin{tabular}{|c|c|c|c|}
\hline Class & E.C $\left(\mathrm{dsm}^{-1}\right)$ & Salinity status & Suitability \\
\hline $\mathrm{C}_{1}$ & $0.0-1.0$ & Low salinity water & Excellent \\
\hline $\mathrm{C}_{2}$ & $1.01-2.0$ & Medium salinity water & Good \\
\hline $\mathrm{C}_{3}$ & $2.01-4.0$ & Salinity water & Injurious \\
\hline $\mathrm{C}_{4}$ & $4.01-6.0$ & High salinity water & Unsuitable \\
\hline $\mathrm{C}_{5}$ & $>6.0$ & Very high salinity water & \\
\hline
\end{tabular}


IRA-International Journal of Applied Sciences

Table:4.Classification of irrigation water based on Sodium Absorption Ratio

\begin{tabular}{|c|c|c|}
\hline Class & SAR & Suitability \\
\hline S1 & $<10$ & Safe \\
\hline S2 33 & $10.01-20.0$ & Moderate \\
\hline
\end{tabular}

Table:5.Classification of irrigation water based on Residual Sodium Carbonate

\begin{tabular}{|c|c|c|}
\hline Class & RSC (Meq/lit) & Suitability \\
\hline R1 & $<1.25$ & Safe \\
\hline R2 & $1.26-2.50$ & Moderate \\
\hline R3 & $>2.50$ & Unsafe \\
\hline
\end{tabular}

Table:6.Problems associated with some geo chemical types of water

\begin{tabular}{|l|l|}
\hline $\mathrm{CaHCO}_{3}$ & Low concentration, no problem \\
\hline $\mathrm{NaHCO}_{3}$ & Intermediate concentration, alkalinity problem \\
\hline $\mathrm{MgHCO}_{3}$ & Low concentration, no problem \\
\hline $\mathrm{NaCl}$ & High concentration, salinity or alkalinity problem \\
\hline $\mathrm{CaCl}$ & High concentration, salinity problems \\
\hline $\mathrm{MgCl}$ & High concentration, moderate salinity problems \\
\hline
\end{tabular}


Table:7.Water Samples analysis Average Values of Costal Revenue Village Sirkazhi Taluk-Tamilnadu

\begin{tabular}{|c|c|c|c|c|c|c|c|c|c|c|c|c|c|c|c|c|c|c|c|}
\hline \multirow[b]{2}{*}{$\begin{array}{l}\text { S. } \\
\text { no }\end{array}$} & \multirow[b]{2}{*}{ VILLAGE NAME } & \multirow[b]{2}{*}{ T.S } & \multirow[b]{2}{*}{ pH } & \multirow{2}{*}{$\begin{array}{l}\text { EC } \\
\text { (dsm- } \\
\text { 1) }\end{array}$} & \multirow[b]{2}{*}{$\begin{array}{c}\text { TDS } \\
\mathrm{mg} / \mathrm{l}\end{array}$} & \multicolumn{4}{|c|}{ ANIONS/(meq/lit) } & \multicolumn{4}{|c|}{ CATIOMS/(meq/lit) } & \multirow{2}{*}{\begin{tabular}{|c} 
RSC \\
(Meq/lit)
\end{tabular}} & \multirow{2}{*}{$\begin{array}{c}\text { SAR } \\
\text { (Meq/lit) }\end{array}$} & \multicolumn{3}{|c|}{ RATING } & \multirow{2}{*}{\begin{tabular}{|l|}
\multicolumn{1}{|c|}{ Geo } \\
$\begin{array}{l}\text { Chemica } \\
\text { type }\end{array}$
\end{tabular}} \\
\hline & & & & & & $\mathrm{CO}_{3}$ & $\mathrm{HCO}_{3}$ & $\mathrm{Cl}$ & $\mathrm{SO}_{4}$ & $\mathbf{C a}$ & Mg & $\mathrm{Na}$ & $\mathbf{K}$ & & & $\begin{array}{c}\mathrm{EC}(\mathrm{dsm}- \\
\text { 1) }\end{array}$ & $\begin{array}{l}\text { SA } \\
\text { R }\end{array}$ & RSC & \\
\hline 1 & \begin{tabular}{|l|} 
ALAKUDI \\
\end{tabular} & 3 & 7.85 & 2.033 & 1301.33 & 0.1 & 9.9233 & 10.166 & 0.1733 & 4.196 & 6.236 & 9.72 & 0.25 & 1.9 & 4.1466 & $\mathrm{C} 3$ & S1 & $\mathbf{R} 2$ & $\mathrm{NaCl}$ \\
\hline 2 & MEHENTRAPALLI & 3 & 7.69 & 1.693 & 1083.66 & $\ldots$ & 9.9233 & 7.606 & 0.1066 & 6.033 & 6.4 & 4.463 & 0.0766 & $\ldots$ & 2.0966 & C2 & S1 & R1 & $\mathrm{MgHCO}_{3}$ \\
\hline 3 & \begin{tabular}{|l|} 
PUTHUPATTINAM \\
\end{tabular} & 3 & 7.76 & 2.226 & 1421.66 & $\ldots$. & 8.8 & 13.166 & 0.3433 & 6.233 & 4.533 & 10.95 & 0.0966 & 0.0966 & 4.82 & C3 & S1 & R1 & $\mathrm{NaCl}$ \\
\hline 4 & MUDHALAI MEDU & 3 & 7.713 & 1.533 & 981 & $\ldots$. & 5.5066 & 6.42 & 0.2066 & 5.003 & 3.956 & 6.386 & 0.1333 & 0.2 & 2.99 & $\mathrm{C2}$ & S1 & R1 & $\mathrm{NaCl}$ \\
\hline 5 & \begin{tabular}{|l|} 
AARAPALLAM \\
\end{tabular} & 3 & 8.056 & 1.47 & 940.66 & 0.333 & 5.54 & 8.7 & 0.1866 & 3.866 & 5.196 & 5.94 & 0.1166 & 0.033 & 2.7366 & $\mathrm{C2}$ & S1 & R1 & $\mathrm{NaCl}$ \\
\hline 6 & \begin{tabular}{|l} 
PULIYANDHURAI \\
\end{tabular} & 3 & 7.676 & 1.776 & 1137 & $\cdots$ & 8.966 & 8.766 & 0.1533 & 4.646 & 7.146 & 5.876 & 0.1133 & 0.0166 & 2.4166 & C2 & ST & RT & $\mathrm{MgHCO}_{3}$ \\
\hline 7 & \begin{tabular}{|l|} 
THANDAVANGULAM \\
\end{tabular} & 3 & 7.716 & 1.05 & \begin{tabular}{|l|}
671.66 \\
\end{tabular} & 0.1333 & 7.033 & 3.1 & 0.25 & 3.733 & 2.766 & 3.993 & 0.02 & 0.7 & 2.17 & C2 & S1 & R1 & $\mathrm{NaHCO}_{2}$ \\
\hline 8 & \begin{tabular}{|l|} 
PAZHAIYAPALAIYAM \\
\end{tabular} & 3 & 7.833 & 2.39 & 1529.66 & 0.2 & 7.966 & 15.4 & 0.3466 & 5 & 4.433 & 14.456 & 0.0266 & $\ldots$ & 5.4366 & \begin{tabular}{|l|}
$\mathrm{C3}$ \\
\end{tabular} & S1 & $\bar{R} 1$ & $\mathrm{NaCl}$ \\
\hline 9 & MAADHANAM & 3 & 8.18 & 1.03 & 659 & $\cdots$ & 6.3 & 3.766 & 0.25 & 3.633 & 2.333 & 4.333 & 0.0166 & 0.9333 & 2.4366 & C2 & S1 & $\overline{\text { R1 }}$ & $\mathrm{NaHCO}_{3}$ \\
\hline 10 & \begin{tabular}{|l} 
KATTUR \\
\end{tabular} & $\overline{3}$ & 7.753 & 1.43 & 9915.33 & $\ldots$. & 6.633 & 7.266 & 0.25 & 7.733 & 5.566 & 3.41 & \begin{tabular}{|l}
0.0133 \\
\end{tabular} & $\ldots$ & 1.67 & C2 & S1 & R1 & $\mathrm{CaCl}$ \\
\hline 11 & \begin{tabular}{|l} 
AHARAVATTARAM \\
\end{tabular} & 3 & 7.593 & 1.166 & 746.66 & $\cdots$. & 7.166 & 4.3 & 0.2166 & 3.533 & 2.733 & 5.396 & 0.0166 & 1.0333 & 2.9466 & \begin{tabular}{|l|} 
C2 \\
\end{tabular} & S1 & $\bar{R} 1$ & $\mathrm{NaHCO} 3$ \\
\hline 12 & MAHARAJAPURAM & 3 & 7.853 & 1.843 & 1179.33 & $\cdots$ & 9.466 & 8.7 & 0.2833 & 4.3 & 3.866 & 10.26 & 0.02 & 1.3 & 5.0233 & C2 & S1 & $\mathbf{R 2}$ & $\mathrm{CaHCO}_{3}$ \\
\hline 13 & VETTANGUDI & 3 & 7.626 & 1.91 & 1222.33 & $\cdots$ & 6.7 & 12 & 0.37 & 7.633 & 4.933 & 6.516 & 0.0166 & $\cdots$ & 2.4833 & C2 & S1 & $\mathbf{R 1}$ & $\mathrm{CaCl}$ \\
\hline 14 & ALANGADU & 3 & 7.846 & 1.17 & 751.33 & 0.1333 & 7.8 & 3.666 & 0.1066 & 3.133 & 2.733 & 5.833 & 0.02 & 2.0666 & 3.3966 & $\mathrm{C2}$ & S1 & $\overline{\mathrm{R} 2}$ & $\mathrm{NaHCO}_{3}$ \\
\hline 15 & KADAVASAL & 3 & 7.676 & 0.946 & 605.66 & 0.0333 & 6.566 & 2.8 & 0.0666 & 3.133 & 3 & $\mathbf{3 . 3 3 3}$ & 0.0166 & 0.4666 & 1.8966 & \begin{tabular}{|l|} 
C1 \\
\end{tabular} & S1 & R1 & NaHCO \\
\hline 16 & VARISAIPATHU VADAKAL & $\overline{3}$ & 7.96 & 0.923 & 591 & 0.2666 & 6.266 & 2.633 & 0.07 & 3.1 & 2.666 & 3.446 & 0.0166 & 0.7666 & 2.0533 & C1 & S1 & $\mathbf{R 1}$ & $\mathrm{NaHCO}_{3}$ \\
\hline 17 & \begin{tabular}{|l|} 
THIRUMULLAIVASAL \\
\end{tabular} & 3 & 7.66 & 1.993 & 1276 & $\ldots$ & 7.033 & $\mathbf{1 3 . 8 3 3}$ & 0.7333 & 6.166 & 4.433 & 9.266 & 0.0166 & 0.4666 & 3.9433 & C2 & S1 & $\bar{R} 1$ & $\mathrm{NaCl}$ \\
\hline 18 & \begin{tabular}{|l} 
EDAMANAL \\
\end{tabular} & 3 & 7.916 & 0.993 & 635.66 & 0.2333 & 6.466 & 3.133 & 0.1066 & 3.8 & 2.166 & 3.966 & 0.0133 & 0.6666 & 2.32 & \begin{tabular}{|l|} 
C1 \\
\end{tabular} & S1 & R1 & NaHCO \\
\hline 19 & RADHANALLUR & 3 & 7.97 & 1.27 & 813 & 0.4333 & 6.7 & 5 & 0.5333 & 3.366 & 4.3 & 4.006 & 0.01 & 0.1 & 2.8033 & C2 & S1 & R1 & $\mathrm{MgHCO}^{3}$ \\
\hline 20 & \begin{tabular}{|l|} 
THIRUKARAIKKAYUR \\
\end{tabular} & 3 & 7.9 & 1.426 & 912.66 & 0.8666 & 6.566 & 6.733 & 0.09 & 4.766 & 5.433 & 4.226 & 0.0166 & 0.8666 & 2.2333 & \begin{tabular}{|c|} 
C2 \\
\end{tabular} & S1 & $\mathbf{R 1}$ & $\mathbf{M g C l}$ \\
\hline 21 & \begin{tabular}{|l|} 
THIRUNAHARI \\
\end{tabular} & 3 & 7.63 & 1.533 & 994.33 & $\cdots$ & 7.466 & 7.333 & 0.58 & 5.733 & 4.666 & 5.1 & 0.0166 & $\cdots$ & 1.5866 & C2 & S1 & $\overline{R 1}$ & $\mathrm{CaHCO}_{3}$ \\
\hline 22 & \begin{tabular}{|l|} 
THENNAMPATTINAM \\
\end{tabular} & 3 & 7.91 & 2.043 & 1308 & 0.2666 & 8.666 & 11.333 & 0.1733 & 4.3 & 5.233 & 10.923 & 0.0266 & 1.1333 & 4.84 & C3 & S1 & R1 & $\mathrm{NaCl}$ \\
\hline 23 & \begin{tabular}{|l} 
NEPATHUR \\
\end{tabular} & 3 & 7.676 & 1.49 & 953.66 & $\ldots$ & 6.466 & 7.566 & 0.7733 & 5.5 & 5.1 & 4.296 & 0.0166 & 0.7333 & 2.1333 & C2 & S1 & R1 & $\mathrm{CaCl}$ \\
\hline 24 & MANGAIMADAM & 3 & 7.25 & 1.916 & 1226.66 & $\cdots$ & 9.433 & 9.333 & 0.4166 & 4.633 & 4.366 & 10.163 & $\begin{array}{l}0.0233 \\
\end{array}$ & 0.7666 & 4.52 & C2 & S1 & R1 & $\mathrm{NaHCO}_{3}$ \\
\hline 25 & MUTHAL PERUNHOTTAM & 3 & 7.613 & 2.266 & 1450.66 & $\ldots$ & 9.633 & 12.6 & 0.4466 & 5.5 & 4.433 & 13.06 & 0.0233 & 0.2666 & 5.9633 & C3 & ST & RT & $\mathrm{NaCT}$ \\
\hline 26 & \begin{tabular}{|l|} 
IRANDAMPERUNTHOTTAM \\
\end{tabular} & 3 & 7.796 & 1.61 & 1030.33 & 0.2 & 9.6 & 6.1 & 0.2166 & 4.5 & 3.966 & 7.623 & 0.0233 & 1.3333 & $\mathbf{3 . 7 0 3 3}$ & C2 & S1 & $\mathbf{R} 2$ & $\mathrm{NaHCO}_{3}$ \\
\hline 27 & \begin{tabular}{|l|} 
AHARA PERUNTHOTTAM \\
\end{tabular} & 3 & 7.77 & 2.1 & 1344 & 0.2 & 10.066 & 10.333 & 0.4166 & 5 & 4.533 & 11.46 & 0.02 & 0.7333 & 5.2833 & $\mathrm{C3}$ & S1 & $\overline{\mathbf{R} 1}$ & $\mathrm{NaCl}$ \\
\hline 28 & \begin{tabular}{|l|} 
MANIKIRAMAM \\
\end{tabular} & 3 & 7.74 & 1.203 & 770.33 & 0.06 & 7.4 & 4.366 & 0.21 & 3.7 & 2.733 & 5.596 & 0.0166 & 1.0333 & 3.06 & $\mathbf{C 2}$ & S1 & R1 & $\mathrm{NaHCO}_{3}$ \\
\hline 29 & MELAIYUR & 3 & 8.103 & 1.526 & 977 & 0.333 & 7.6 & 7.133 & 0.2033 & 4 & 3 & 8.27 & 0.0166 & 1.1666 & 4.3 & $\mathrm{C2}$ & S1 & R1 & $\mathrm{NaHCO}_{3}$ \\
\hline
\end{tabular}


IRA-International Journal of Applied Sciences

\begin{tabular}{|c|c|c|c|c|c|c|c|c|c|c|c|c|c|c|c|c|c|c|c|}
\hline 30 & KEEZHAIYUR & 3 & 7.726 & 1.193 & 763.33 & 0.0333 & 7.833 & 3.966 & 0.1066 & 4.333 & 2.9 & 4.7 & 0.0233 & 0.6333 & 2.47 & C2 & S1 & R1 & $\mathrm{NaHCO}_{3}$ \\
\hline 31 & VANAKIRI & 3 & 7.786 & 1.636 & 1049 & 0.2666 & 9.4 & 6.633 & 0.14 & 4.133 & 3.166 & 9.096 & 0.0333 & 2.3666 & 4.72 & $\overline{\mathrm{C2}}$ & S1 & $\overline{\mathrm{R3}}$ & $\mathrm{NaHCO}_{2}$ \\
\hline 32 & ALALASUNTHARAM & 3 & 7.883 & 1.23 & 787 & 0.0666 & 6.233 & 5.8 & 0.21 & 2.9933 & 6.08 & 0.2 & 0.03 & 0.2666 & 2.8766 & $\mathrm{C}^{2}$ & ST & RT & $\mathrm{MgHCO}_{3}^{3}$ \\
\hline 33 & ACHALAPURAM & 3 & 7.946 & 1.383 & 865.33 & $\ldots$ & 9.333 & 4.34 & 0.16 & 5.466 & 4.066 & 4.106 & 0.08 & $\ldots .$. & 2.21 & $\mathrm{C2}$ & S1 & R1 & $\mathrm{CaHCO}_{3}$ \\
\hline 34 & NALLANAYAKKA PURAM & 3 & 7.536 & 1.106 & 708 & $\cdots$ & 5.773 & 5.153 & 0.15 & 3.54 & 3.08 & 4.376 & 0.0966 & 0.0666 & 2.3566 & $\mathrm{C2}$ & S1 & R1 & $\mathrm{NaHCO}_{2}^{3}$ \\
\hline 35 & OMAIYAL PETTAI & 3 & 7.556 & 2.373 & 1519 & 0.1666 & 10.033 & 13.133 & 0.42 & 4.866 & 4.7 & 14.156 & 0.02 & 0.5666 & 6.3166 & $\mathrm{C3}$ & ST & RT & $\mathrm{NaCT}$ \\
\hline 35 & RANGE & -- & $\begin{array}{l}7.25- \\
8.18\end{array}$ & $\begin{array}{l}0.923- \\
2.39\end{array}$ & \begin{tabular}{|l|}
$591-$ \\
1529.6
\end{tabular} & $\begin{array}{l}0.033- \\
0.866\end{array}$ & $\begin{array}{l}5.506- \\
10.066\end{array}$ & \begin{tabular}{|l|}
$2.8-$ \\
15.4
\end{tabular} & $\begin{array}{l}0.066- \\
0.773\end{array}$ & $\begin{array}{l}2.9933- \\
7.733\end{array}$ & $\begin{array}{l}2.166- \\
7.14\end{array}$ & $\begin{array}{l}0.2- \\
14.456\end{array}$ & $\begin{array}{l}0.01- \\
0.1333\end{array}$ & $\begin{array}{l}0.1- \\
2.3666\end{array}$ & $\begin{array}{l}1.586- \\
6.3166\end{array}$ & -- & $\cdots-$ & -.- & -.--- \\
\hline 37 & MEAN & 3 & 7.556 & 1.567 & 1003.46 & 0.12263 & 7.7787 & 7.4936 & 0.2704 & 4.6058 & 4.195 & 14.156 & 0.0426 & 0.647954 & $\mathbf{3 . 3 2 4 5}$ & $\mathrm{C}_{2}$ & s1 & R1 & $\mathrm{NaHCO}_{3}$ \\
\hline
\end{tabular}

